\title{
Effect of Cobalt Doping and Milling Time on Microstructure and Vickers Microhardness of the Spark Plasma Sintered (67-x)Ti-xCo-22Si-11B (x = 2 and 6 at-\%) Alloys
}

\author{
Nelson Damásio Ferreira ${ }^{a}$, Ricardo Mendes Leal Neto ${ }^{b}$ @i), Marcello Filgueira ${ }^{c}$, \\ Manuel Fellipe Rodrigues Pais Alves ${ }^{d}$, Claudinei dos Santos ${ }^{e}$, Alfeu Saraiva Ramos ${ }^{a *}$ (1) \\ ${ }^{a}$ Universidade Federal de Alfenas, Instituto de Ciência e Tecnologia, Rodovia José Aurélio Vilela, \\ 11999, 37715-400, Poços de Caldas, MG, Brasil \\ ${ }^{b}$ Instituto de Pesquisas Energéticas e Nucleares. Av. Prof. Lineu Prestes, 2242, \\ Cidade Universitária, Butantã, 05508-000, São Paulo, SP, Brasil \\ ${ }^{c}$ Universidade Estadual do Norte Fluminense Darcy Ribeiro, Avenida Alberto Lamengo, 200, \\ Parque Califórnia, 28013-602, Campos de Goytacazes, RJ, Brasil \\ ${ }^{d}$ Escola de Engenharia de Lorena, Universidade de São Paulo, Polo Urbo Industrial, Gleba AI-6, \\ 12602-810, Lorena, SP, Brasil \\ ${ }^{e}$ Universidade do Estado do Rio de Janeiro, Faculdade de Tecnologia de Resende, Rodovia Presidente \\ Dutra km 298, Polo Industrial de Resende, 27537-000, Resende, RJ, Brasil
}

Received: July 25, 2020; Revised: October 16, 2020; Accepted: November 2, 2020

\begin{abstract}
Ti-6Al-4V and TiAl-based alloys are widely used for fabricating the implantable orthopedic devices and automotive components, respectively. $\mathrm{Ti}_{6} \mathrm{Si}_{2} \mathrm{~B}$-based alloys are attractive for use in orthopedic components because their higher hardness, superior biocompatibility and corrosion resistance in simulated body fluid than Ti and Ti-6Al-4V alloy. Limited information on $\mathrm{Ti}_{6} \mathrm{Si}_{2} \mathrm{~B}$ stability in Co-dopped 67Ti-22Si-11B alloys are available in literature. This work presents the effect of cobalt doping and milling time on microstructure and Vickers microhardness of 65Ti-2Co-22Si-11B and 61Ti-6Co-22Si-11B (at-\%) alloys produced by spark plasma sintering at $1100^{\circ} \mathrm{C}$ for $12 \mathrm{~min}$ using $20 \mathrm{MPa}$. Samples were characterized by $\mathrm{X}$ ray diffraction, scanning electron microscopy, energy dispersive spectrometry, laser particle size analysis, and Vickers microhardness. Sintered alloys with 2 and 6at-\%Co indicated the major presence of $\mathrm{Ti}_{6} \mathrm{Si}_{2} \mathrm{~B}$ and $\mathrm{Ti}_{5} \mathrm{Si}_{3}$ dissolving up to 2.7 and 4.2 at- $\% \mathrm{Co}$, respectively, besides the minor precipitates of $\mathrm{CoTi}_{2}(4.4-16.7 \mathrm{at}-\% \mathrm{Si})$ and $\mathrm{CoTi}(4.6-4.7 \mathrm{at}-\% \mathrm{Si})$. Vickers microhardness of the sintered $65 \mathrm{Ti}-2 \mathrm{Co}-22 \mathrm{Si}-11 \mathrm{~B}$ and $61 \mathrm{Ti}-6 \mathrm{Co}-22 \mathrm{Si}-11 \mathrm{~B}$ alloys were in the range of $950-1050$ and $1050-1150 \mathrm{HV}$, respectively. Although the increase from 2 to $6 \mathrm{at}-\% \mathrm{Co}$ has reduced the $\mathrm{Ti}_{6} \mathrm{Si}_{2} \mathrm{~B}$ stability, the Co-rich phases increased their hardness values up to $1150 \mathrm{HV}(11.3 \mathrm{GPa})$, which are superior than those of commercial Ti alloys used for joint orthopedic components and automotive rotating parts.
\end{abstract}

Keywords: titanium alloys, cobalt, implants, automotive, sintering.

\section{Introduction}

$\mathrm{Ti}_{6} \mathrm{Si}_{2} \mathrm{~B}$-based alloys with high hardness, corrosion resistance, and good biocompatibility and bone integration characteristics are potentially attractive for fabricating of articular orthopedic components ${ }^{1,2}$. Moreover, these high hardness values are also desirable for rotating components used in automotive applications ${ }^{3}$. Nonetheless, the use of alloying and its effect on phase transformations during processing and specific mechanical properties are important. Previous studies on phase transformations in mechanical alloyed (67-x)Ti-xMe-22Si-11B (x $\leq 6$ at-\%) powders containing the $\mathrm{Sn}^{4}$ or $\mathrm{Zr}^{5}$ addition lower than 2 and 6 at- $\%$ can produce microstructures based on $\mathrm{Ti}_{6} \mathrm{Si}_{2} \mathrm{~B}$. For higher amounts, the $\mathrm{Ti}_{5} \mathrm{Si}_{3}$ or $\mathrm{Ti}_{3} \mathrm{Si}$ phases dissolving alloying elements are preferentially formed instead the $\mathrm{Ti}_{6} \mathrm{Si}_{2} \mathrm{~B}$ phase in the Ti-Si-B alloys containing alloying addition. Depending on milling

*e-mail: alfeu.ramos@unifal-mg.edu.br. time adopted, the $\mathrm{Ti}_{6} \mathrm{Si}_{2} \mathrm{~B}$ phase was preferentially formed in microstructures of these quaternary alloys.

In this regard, the Ti alloys with cobalt addition are considered for biomedical applications due to their wear resistance and biocompatibility, which are produced by conventional melting and powder metallurgy techniques ${ }^{6-10}$. Porous Co-Ti alloys are prepared by powder metallurgy using the space holder technique ${ }^{9}$. $\mathrm{CoTi}_{2}$ and $\alpha$-Ti were identified in microstructure of Ti-4Co (wt.-\%) alloy prepared by high-pressure torsion ${ }^{11}$. In contrast, the dense $\mathrm{TiC}_{\mathrm{x}} \mathrm{N}_{(1-\mathrm{x})}-15 \mathrm{wt}-\%$ Co cermet materials were produced by mechanical alloying and subsequent spark plasma sintering, which presented an interesting combination of high hardness, fracture toughness and bending strength ${ }^{12}$.

According to phase diagram of the Co-Ti system ${ }^{13}$, the small Co amount lower than 1 and 15 at- $\%$ can dissolve at low and high temperatures in $\alpha$-Ti and $\beta$-Ti, respectively. Larger Ti amounts close to 2 and 9 at- $\%$ are dissolved into 
the Co lattices at low and high temperatures, respectively. The following intermediate phases are presents in this binary phase diagram: $\mathrm{CoTi}_{2}, \mathrm{CoTi}, \mathrm{C} 15$ ( 26.6 at- $\left.\% \mathrm{Co}\right)$, $\mathrm{C} 36$ ( $\sim 69$ at- $\% \mathrm{Co})$ and $\mathrm{Co}_{3}$ Ti. CoTi exhibits a homogeneity range at low temperatures between 50 and 54 at- $\%$ Co. CoTi and $\mathrm{TiCo}_{2}$ are formed by congruent transformations whereas the $\mathrm{Ti}_{2} \mathrm{Co}, \mathrm{C} 15$ and $\mathrm{C} 36$ occur by peritectic reactions.

No information was found in literature on effect of cobalt addition in phase transformations of Ti-Si-B alloys. In this sense, this work discusses on effect of cobalt doping and milling time on phase transformation of $65 \mathrm{Ti}-2 \mathrm{Co}-22 \mathrm{Si}-11 \mathrm{~B}$ and Ti-6Co-22Si-11B (at-\%) alloys produced by spark plasma sintering.

\section{Experimental Procedure}

In this work, the 65Ti-2Co-22Si-11B and 61Ti-6Co22Si-11B (at-\%) alloys were prepared by high-energy ball milling and subsequent spark plasma sintering (SPS). The following starting powders (Alfa Aesar, Ward Hill, MA, USA) were used to prepare these elemental powder mixtures: Ti (spherical, 99.9wt.-\%), Si (irregular, 99.999wt.-\%), and B (angular, 99.5 wt.-\%). Cobalt granules with 99 wt.- $\%$ purity (Dinâmica Ltda., Indaiatuba, SP, Brazil) were used to prepare the quaternary alloys. In order to evaluate the effect of cobalt addition on the $\mathrm{Ti}_{6} \mathrm{Si}_{2} \mathrm{~B}$ stability, the added amounts were chosen in accordance with previous works involving the Ti-Sn-Si-B ${ }^{4}$ and Ti-Zr-Si-B ${ }^{5}$ alloys produced by similar route with same alloying amounts.

Ball milling from elemental Ti-Co-Si-B powder mixtures was performed in a planetary Fritsch P-5 mill (Fritsch $\mathrm{GmbH}$, Idar-Oberstein, Germany) under argon atmosphere using WC-6Co vials (225 mL) and balls (19 mm diameter), rotary speed of $300 \mathrm{rpm}$ and a ball-to-powder weight ratio of 10:1. To understand the effect of milling time on phase transformation, the elemental Ti-Co-Si-B powder mixtures were milled at different times (20,60, and $300 \mathrm{~min})$, which are based on the previous work ${ }^{4}$.

In the sequence, the Ti-Co-Si-B powders previously milled at different times were then consolidated by spark plasma sintering (SPS) in a Dr. Sinter - fdc SPS division model SPS-211LX sintering machine (FUJI Electron Industrial. Co. LTD) at $1100{ }^{\circ} \mathrm{C}$ for $12 \mathrm{~min}$ (minimum time to obtain high densification) under low vacuum $\left(3.3 \times 10^{-3}\right.$ to $1 \times 10^{-5} \mathrm{~Pa}$ ) with a heating rate of $65^{\circ} \mathrm{C} / \mathrm{min}$, using axial pressure of $20 \mathrm{MPa}$ and a graphite die in order to obtain the cylinder specimens with $10 \mathrm{~mm}$ diameter. The temperature was measured by placing the radial pyrometer focused on the graphite die.

The as-milled Ti-Co-Si-B powders and the SPSed samples were evaluated by X-ray diffraction (XRD), scanning electron microscopy (SEM), energy dispersive spectrometry (EDS), laser diffraction particle size analysis. Furthermore, sintered samples were characterized by relative density using Arquimedes method and Vickers microhardness tests.

XRD experiments at room temperature of Ti-Co-Si-B samples were performed in a Panalytical model Empyrean equipment (PANalytical, Almelo, The Netherlands) using $\mathrm{Cu}-\mathrm{K} \alpha$ radiation and a Ni filter, voltage of $40 \mathrm{kV}$, current of $30 \mathrm{~mA}$, diffraction angle $(2 \theta)$ in the range from 20 to $80^{\circ}$, angular pass of $0.02^{\circ}$ and counting time per pass of $80 \mathrm{~s}$.
The Pearson' crystal data ${ }^{14}$ and the Powdercell computer program ${ }^{15}$ were used to index the phases in XRD patterns of as-milled powders and SPSed samples. The values of lattice parameters, unit cell volume, and interplanar distance (d) of the $\alpha$-Ti and bcc-Si peaks in Ti-Co-Si-B powder mixtures as well as their major diffraction angles $(2 \theta)$ and relative phase amounts were calculated by Rietveld refining using the FullProf 2.7.9 program $^{16}$. The crystallite sizes (D) of $\alpha$-Ti and bcc-Si in as-milled Ti-Co-Si-B powders were calculated using the Scherrer equation ${ }^{17,18}$.

SEM micrographs of as-milled Ti-Co-Si-B powders and their SPSed samples were obtained in a Hitachi model TM3000 SEM (Hitachi High-Technologies Corporation (TOKYO, Japan) using backscattered electron detector, whereas the $\mathrm{Ti}, \mathrm{Co}$ and $\mathrm{Si}$ contents of phases formed in SPSed Ti-Co-Si-B samples were measured by EDS analysis using inner patterns. In SPSed Ti-Co-Si-B alloys, the samples were carefully prepared by conventional metallographic practices i.e., the sanding with $\mathrm{SiC}$ sandpapers (120, 200, 320, 400, 600 and 1200 \#) and polishing with colloidal silica suspension. No chemical attack was needed for the microstructural characterization of these quaternary alloys. To identify the Ti, Si, B and Co distributions in microstructures of the SPSed 61 Ti-6Co-22Si-11B alloy, the X-ray mapping was also conducted in SEM analysis.

The particle size distribution of as-milled Ti-Co-Si-B powders was performed by laser diffraction experiments in a Malvern Instruments model Mastersizer 2000 equipment (Malvern, Worcestershire, United Kingdom), using water as dispersant medium and Fraunhofer particle size. To measure the volume of fine particles, mean particle sizes and coarse particles in as-milled Ti-Co-Si-B powders, the values of D10, D50 and D90, which are the intercepts for $10 \%, 50 \%$ and $90 \%$ of the cumulative volume, respectively, were determined.

In order to correlate the microstructures and mechanical behavior of the SPSed Ti-Co-Si-B alloys, the values of Vickers microhardness were obtained in a Buehler model Micromet 6020 microhardness tester (Buehler, Lake Bluff, Illinois, USA) in accordance to the ASTM E-384 standard ${ }^{19}$ using a load of $96 \mathrm{~N}$ under a loading rate of $0.01 \mathrm{~mm} / \mathrm{s}$. The average Vickers microhardness values were obtained in representative regions from ten measurements for each sample.

\section{Results and Discussion}

Figure 1 shows the XRD patterns of $65 \mathrm{Ti}-2 \mathrm{Co}-22 \mathrm{Si}-11 \mathrm{~B}$ and $61 \mathrm{Ti}-6 \mathrm{Co}-22 \mathrm{Si}-11 \mathrm{~B}$ powder mixtures at different milling times. Peaks of $\alpha$-Ti, Si and Co were initially identified in powders milled for $20 \mathrm{~min}$. Coherently, the Co peaks were more accentuated in Co-richer powder mixture. As expected, the relative intensity of peaks was promptly reduced for longer milling times due to severe plastic deformation and/or solid-state elemental dissolution during ball milling. Moreover, the Co peaks disappeared after milling for 60 and $300 \mathrm{~min}$ in $65 \mathrm{Ti}-2 \mathrm{Co}-22 \mathrm{Si}-11 \mathrm{~B}$ and $61 \mathrm{Ti}-6 \mathrm{Co}-22 \mathrm{Si}-11 \mathrm{~B}$ powders, respectively. Traces of $\mathrm{Si}$ and $\alpha$-Ti peaks were identified in 65Ti-2Co-22Si-11B powders milled for $300 \mathrm{~min}$, whereas only the peaks of $\mathrm{Ti}_{5} \mathrm{Si}_{3}$ and $\mathrm{TiB}$ were indexed in XRD patterns of $61 \mathrm{Ti}-6 \mathrm{Co}-22 \mathrm{Si}-11 \mathrm{~B}$ powders milled for $300 \mathrm{~min}$ only. It was noted that the $\alpha$-Ti peaks were slightly moved in the direction of larger diffraction angles $(2 \theta)$, suggesting 
that $\mathrm{Si}, \mathrm{B}$ and/or Co atoms were dissolved into its crystalline structure to form supersaturated solid solutions. According to the phase diagram of the $\mathrm{Co}-\mathrm{Ti}^{13}, \mathrm{~B}-\mathrm{Ti}^{20}$ and $\mathrm{Si}-\mathrm{Ti}^{21}$ systems, the $\alpha$-Ti can dissolve the cobalt (or boron) and silicon amounts lower than 1 and 2 at- $\%$, respectively. However, no intermediate intermetallic phase based on the Co-Ti, Co-B or Co-Si system was formed during ball milling from the elemental Ti-Co-Si-B powder mixtures.

The relative phase amounts in $65 \mathrm{Ti}-2 \mathrm{Co}-22 \mathrm{Si}-11 \mathrm{~B}$ and 61Ti-6Co-22Si-11B powders are presented in Table 1, which were determined by Rietveld refining. Independently on powder composition, the amounts of $\alpha$-Ti were continuously increased whereas the amounts of Si were reduced during ball milling of these powder mixtures. Cobalt was not measured due to its relatively small amounts in these powder mixtures.

Table 2 shows the values of lattice parameters and unit cell volume of $\alpha$-Ti and bcc-Si in Ti-Co-Si-B powders milled at different times, which were determined by Rietveld refining. Titanium, cobalt, silicon and boron possesses atomic radium (covalent radium) of 140 (136) pm, 126 (152) pm, 111 (111) pm and 87 (82) pm, respectively. Initially, the $\alpha$-Ti presents the $a$ and $c$ lattice parameters of 0.29616 and $0.47589 \mathrm{~nm}$, respectively with unit cell volume of $0.0361 \mathrm{~nm}^{3}$. Our results
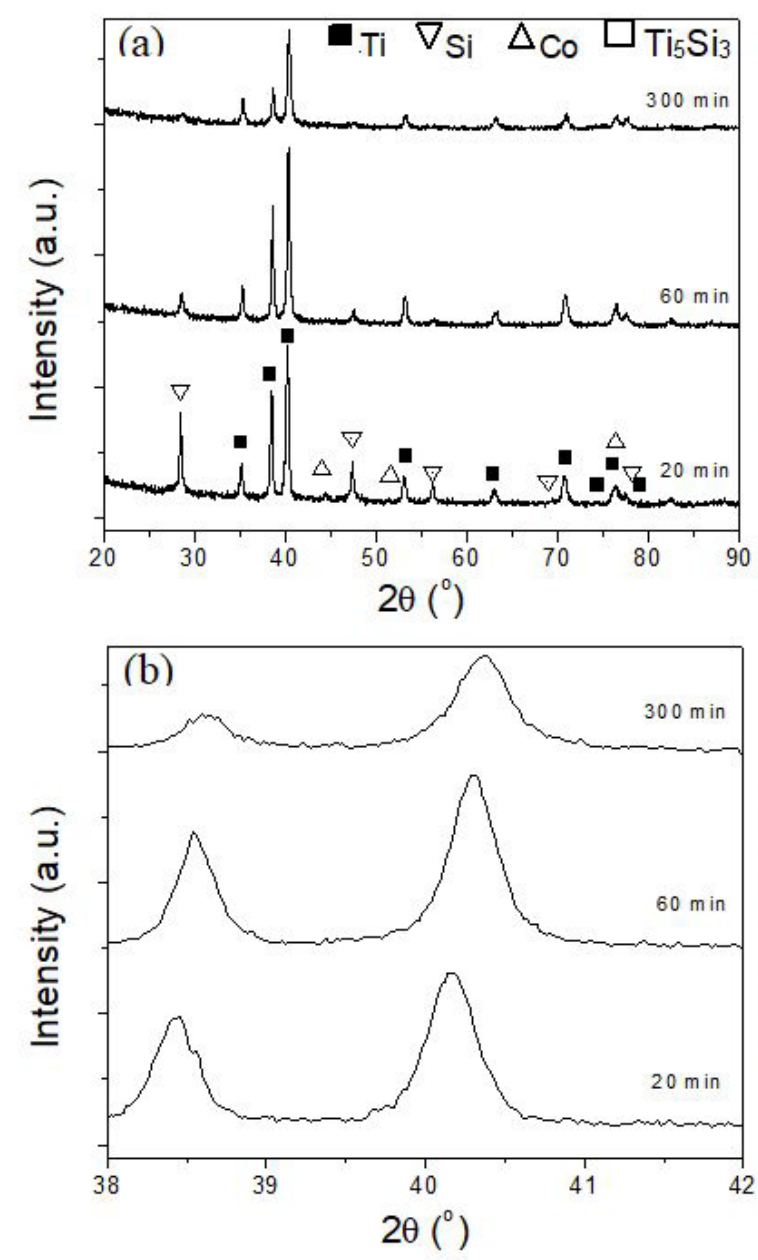

have indicated that these values were slightly reduced during ball milling of $65 \mathrm{Ti}-2 \mathrm{Co}-22 \mathrm{Si}-11 \mathrm{~B}$ and $61 \mathrm{Ti}-6 \mathrm{Co}-22 \mathrm{Si}-11 \mathrm{~B}$ powders which could be related to the elemental dissolution into the $\alpha$-Ti lattice. However, it was not noted any significant change in these values for the Co-richer powders and longer milling times. Bcc-Si presents the lattice parameters and unit cell volume of $0.543 \mathrm{~nm}$ and $0.1601 \mathrm{~nm}^{3}$, respectively. Independently on powder composition and milling time, no significant change in these values was achieved.

Values of interplanar distance (d), crystallite size (D) and major $\alpha-\mathrm{Ti}$ and bcc-Si diffraction angles $(2 \theta)$ in $65 \mathrm{Ti}-$ 2Co-22Si-11B and 61Ti-6Co-22Si-11B powders milled at different times are presented in Table 3, which were determined by Rietveld refining. Excepting to the $65 \mathrm{Ti}-2 \mathrm{Co}-22 \mathrm{Si}-11 \mathrm{~B}$ powders milled for $20 \mathrm{~min}$, the major $\alpha$-Ti peak was broadened and moved in the direction of larger diffraction angles $(2 \theta)$ after milling for 60 and $300 \mathrm{~min}$. These facts are normally related to the crystallographic distortions due to severe plastic deformation and atomic dissolution occurred during milling ${ }^{22}$, suggesting that the powder mixture with lesser cobalt amounts presented superior plastic deformation. However, the released heat from exothermic and partial $\mathrm{Ti}_{5} \mathrm{Si}_{3}$ formation has reduced the metastability of supersaturated
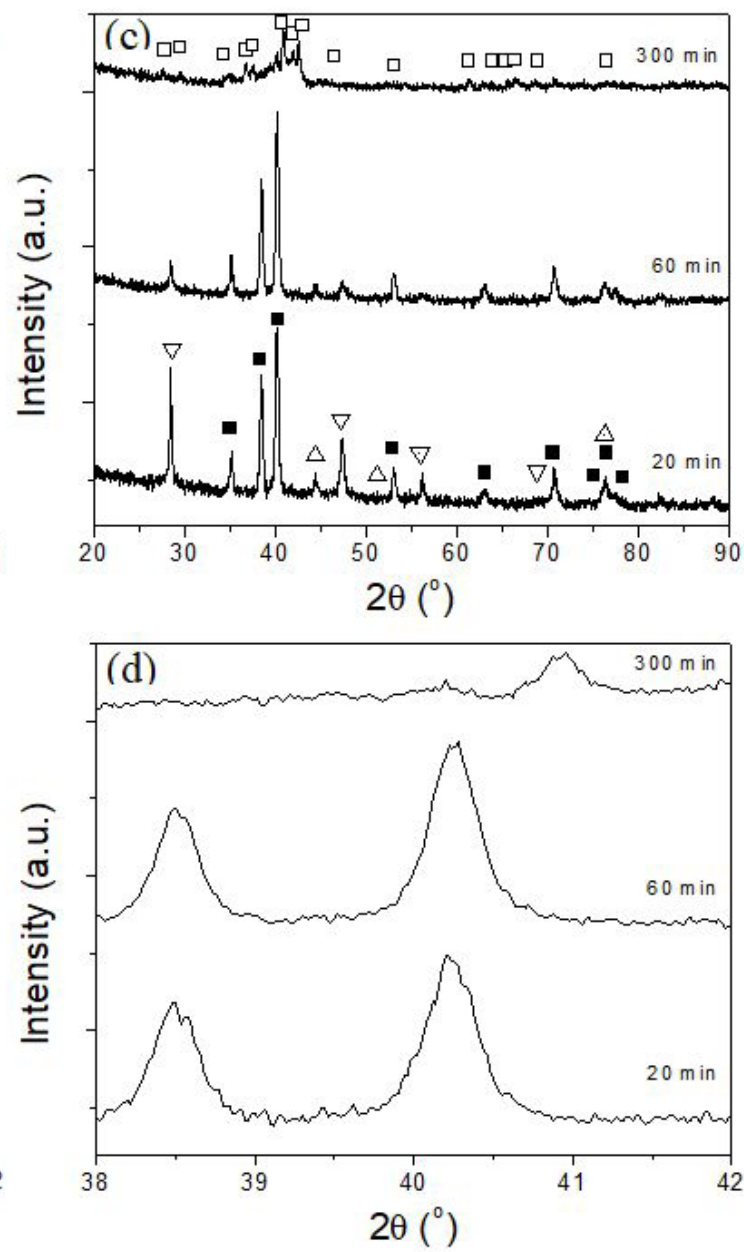

Figure 1. XRD patterns of (a,b) Ti-2Co-22Si-11B and (c,d) Ti-6Co-22Si-11B powder mixtures at different milling times, and their details on their major $\alpha$-Ti peaks are illustrated in (b) and (d), respectively. 
Table 1. Relative phase amounts determined by Rietveld refining in 65Ti-2Co-22Si-11B and 61Ti-6Co-22Si-11B powders milled at different times.

\begin{tabular}{|c|c|c|c|c|c|c|}
\hline \multirow{2}{*}{ Milling Time (min) } & \multicolumn{3}{|c|}{ 65Ti-2Co-22Si-11B } & \multicolumn{3}{|c|}{ 61Ti-6Co-22Si-11B } \\
\hline & $\alpha-\mathrm{Ti}$ & $\mathrm{Si}$ & $\mathrm{Co}$ & $\alpha-\mathrm{Ti}$ & $\mathrm{Si}$ & $\mathrm{Co}$ \\
\hline 20 & 63.6 & 36.4 & --- & 69.6 & 30.4 & --- \\
\hline 60 & 82.2 & 17.6 & --- & 80.8 & 19.2 & --- \\
\hline 300 & 93.4 & 6.1 & $\begin{array}{ll}-- \\
--\end{array}$ & --- & --- & --- \\
\hline
\end{tabular}

Table 2. Lattice parameters and unit cell volume of $\alpha$-Ti and bcc-Si determined by Rietveld refining of Ti-Co-Si-B powders milled at different times.

\begin{tabular}{|c|c|c|c|c|c|c|c|c|}
\hline \multirow[b]{2}{*}{$\begin{array}{l}\text { Milling Time } \\
\text { (min) }\end{array}$} & \multicolumn{4}{|c|}{ 65Ti-2Co-22Si-11B } & \multicolumn{4}{|c|}{ 61Ti-6Co-22Si-11B } \\
\hline & \multicolumn{3}{|c|}{$\begin{array}{l}\alpha-\mathrm{Ti}, \text { Lattice Parameters } \\
(\mathrm{nm})\end{array}$} & \multirow{2}{*}{$\begin{array}{c}\begin{array}{c}\alpha \text {-Ti, Cell Volume } \\
\left(\mathrm{nm}^{3}\right)\end{array} \\
0.03527\end{array}$} & \multicolumn{3}{|c|}{$\begin{array}{c}\alpha \text {-Ti, Lattice Parameters } \\
(\mathrm{nm})\end{array}$} & \multirow{2}{*}{$\begin{array}{c}\begin{array}{c}\alpha-\mathrm{Ti}, \text { Cell Volume } \\
\left(\mathrm{nm}^{3}\right)\end{array} \\
0.03532\end{array}$} \\
\hline 20 & 0.2950 & 0.2950 & 0.4679 & & 0.2951 & 0.2951 & 0.4681 & \\
\hline 60 & 0.2951 & 0.2951 & 0.4683 & 0.03533 & 0.295 & 0.2950 & 0.4683 & 0.03531 \\
\hline \multirow[t]{2}{*}{300} & 0.2948 & 0.2948 & 0.4678 & 0.03521 & ND & ND & ND & ND \\
\hline & \multicolumn{3}{|c|}{$\begin{array}{l}\text { Si, Lattice Parameters } \\
(\mathrm{nm})\end{array}$} & $\begin{array}{l}\mathrm{Si}, \underset{\left(\mathrm{nm}^{3}\right)}{\text { Cell Volume }} \\
\text {. }\end{array}$ & \multicolumn{3}{|c|}{$\begin{array}{l}\text { Si, Lattice Parameters } \\
(\mathrm{nm})\end{array}$} & $\begin{array}{l}\text { Si, Cell Volume } \\
\left(\mathrm{nm}^{3}\right)\end{array}$ \\
\hline 20 & 0.5427 & 0.5427 & 0.5427 & 0.15985 & 0.5429 & 0.5429 & 0.5429 & 0.16004 \\
\hline 60 & 0.5434 & 0.5434 & 0.5434 & 0.16046 & 0.5429 & 0.5429 & 0.5429 & 0.16007 \\
\hline 300 & 0.5421 & 0.5421 & 0.5421 & 0.15931 & ND & ND & ND & ND \\
\hline
\end{tabular}

ND - Not Determined.

Table 3. Interplanar distance (d), crystallite size (D), diffraction angle (20) of major $\alpha$-Ti and bcc-Si peaks in $65 \mathrm{Ti}-2 \mathrm{Co}-22 \mathrm{Si}-11 \mathrm{~B}$ and $61 \mathrm{Ti}-6 \mathrm{Co}-22 \mathrm{Si}-11 \mathrm{~B}$ powders milled at different times, which were determined by Rietveld refining.

\begin{tabular}{|c|c|c|c|c|c|c|}
\hline \multirow{2}{*}{$\begin{array}{l}\text { Milling Time } \\
\quad(\min )\end{array}$} & \multicolumn{3}{|c|}{$\alpha$-Ti in $65 \mathrm{Ti}-2 \mathrm{Co}-22 \mathrm{Si}-11 \mathrm{~B}$} & \multicolumn{3}{|c|}{ bcc-Si in 65Ti-2Co-22Si-11B } \\
\hline & $\begin{array}{c}\text { Interplanar distance, } \\
\mathrm{d}(\mathrm{nm})\end{array}$ & $\begin{array}{c}\text { Crystallite size, } \\
\text { D (nm) }\end{array}$ & $2 \theta,\left({ }^{\circ}\right)$ & $\begin{array}{c}\text { Interplanar distance, } \\
\mathrm{d}(\mathrm{nm})\end{array}$ & $\begin{array}{c}\text { Crystallite size, } \\
\text { D (nm) }\end{array}$ & $2 \theta,\left({ }^{\circ}\right)$ \\
\hline 20 & 0.22451 & 24.2 & 40.133 & 0.31388 & 34.8 & 28.421 \\
\hline 60 & 0.22378 & 24.8 & 40.267 & 0.31267 & 18.8 & 28.521 \\
\hline 300 & 0.22347 & 18.6 & 40.325 & 0.31206 & 9.8 & 28.580 \\
\hline \multirow{2}{*}{$\begin{array}{l}\text { Milling Time } \\
\text { (min) }\end{array}$} & \multicolumn{3}{|c|}{$\alpha$-Ti in 61Ti-6Co-22Si-11B } & \multicolumn{3}{|c|}{ bcc-Si in 61Ti-6Co-22Si-11B } \\
\hline & $\begin{array}{c}\text { Interplanar distance, } \\
\mathrm{d}(\mathrm{nm})\end{array}$ & $\begin{array}{c}\text { Crystallite size, } \\
\text { D (nm) }\end{array}$ & $2 \theta,\left({ }^{\circ}\right)$ & $\begin{array}{c}\text { Interplanar distance, } \\
\mathrm{d}(\mathrm{nm})\end{array}$ & $\begin{array}{c}\text { Crystallite size, } \\
\text { D (nm) }\end{array}$ & $2 \theta,\left({ }^{\circ}\right)$ \\
\hline 20 & 0.22413 & 22.80 & 40.202 & 0.31311 & 33.3 & 28.484 \\
\hline 60 & 0.22404 & 24.58 & 40.219 & 0.31298 & 21.4 & 28.495 \\
\hline 300 & ND & ND & ND & ND & ND & ND \\
\hline
\end{tabular}

ND - Not Determined.

Ti solid solution in powder mixtures with 6 at- $\%$ Co. Peaks of $\mathrm{Ti}_{5} \mathrm{Si}_{3}$ were also identified in $61 \mathrm{Ti}-6 \mathrm{Co}-22 \mathrm{Si}-11 \mathrm{~B}$ powders milled for $300 \mathrm{~min}$. Hence, the FWHM values and diffraction angles of major $\alpha$-Ti peak were not determined, which are indicated in Table 3 as ND (Not Determined).

Figure 2 displays the SEM micrographs of the 65Ti$2 \mathrm{Co}-22 \mathrm{Si}-11 \mathrm{~B}$ and $61 \mathrm{Ti}-6 \mathrm{Co}-22 \mathrm{Si}-11 \mathrm{~B}$ powder mixtures at different milling times. As expected for these powder mixtures containing both ductile and brittle components, the brittle $\mathrm{Si}$ and $\mathrm{B}$ particles were promptly fragmentated whereas the ductile Ti and Co particles suffered severe plastic deformation provided by the impact and shear mechanisms during ball milling. As consequence of large amounts of ductile components, the powder particles or aggregate sizes with rounded morphologies increased during milling up to $60 \mathrm{~min}$, which were subsequently reduced in powders milled for $300 \mathrm{~min}$. This fact was more pronounced in the Co-richer powder mixture due to the in-situ formation of hard and brittle $\mathrm{Ti}_{5} \mathrm{Si}_{3}$ compound.
Values of D10, D50 and D90 as well as the specific surface area measured by laser diffraction experiments in as-milled Ti-Co-Si-B powders are presented in Table 4, whereas their particle size distribution curves are illustrated in Figure 3. According with the SEM observations, the average particle sizes (D50) were continuously increased during milling for $300 \mathrm{~min}$ of the $65 \mathrm{Ti}-2 \mathrm{Co}-22 \mathrm{Si}-11 \mathrm{~B}$ and $61 \mathrm{Ti}-6 \mathrm{Co}-22 \mathrm{Si}-11 \mathrm{~B}$ powders, respectively. Excepting in $61 \mathrm{Ti}-6 \mathrm{Co}-22 \mathrm{Si}-11 \mathrm{~B}$ powders milled for $300 \mathrm{~min}$, the average particle sizes were reduced to $88 \mu \mathrm{m}$ owing mainly the in-situ $\mathrm{Ti}_{5} \mathrm{Si}_{3}$ formation. Bimodal curves of Ti-Co-Si-B powders milled for $20 \mathrm{~min}$ with a slight normal region for finer particles can be also observed in Figure 3. The 65Ti-2Co-22Si-11B powders milled for 60 and $300 \mathrm{~min}$ exhibited unimodal distribution curves. Despite the smaller average particle sizes, the 61Ti-6Co22Si-11B powders milled for 300 min presented a bimodal distribution, indicating the significant existence of coarse particles/aggregates. In this way, the values of specific surface area were reduced from $0.32 / 0.34$ to $0.042 / 0.12 \mathrm{~m}^{2} / \mathrm{g}$ in the 

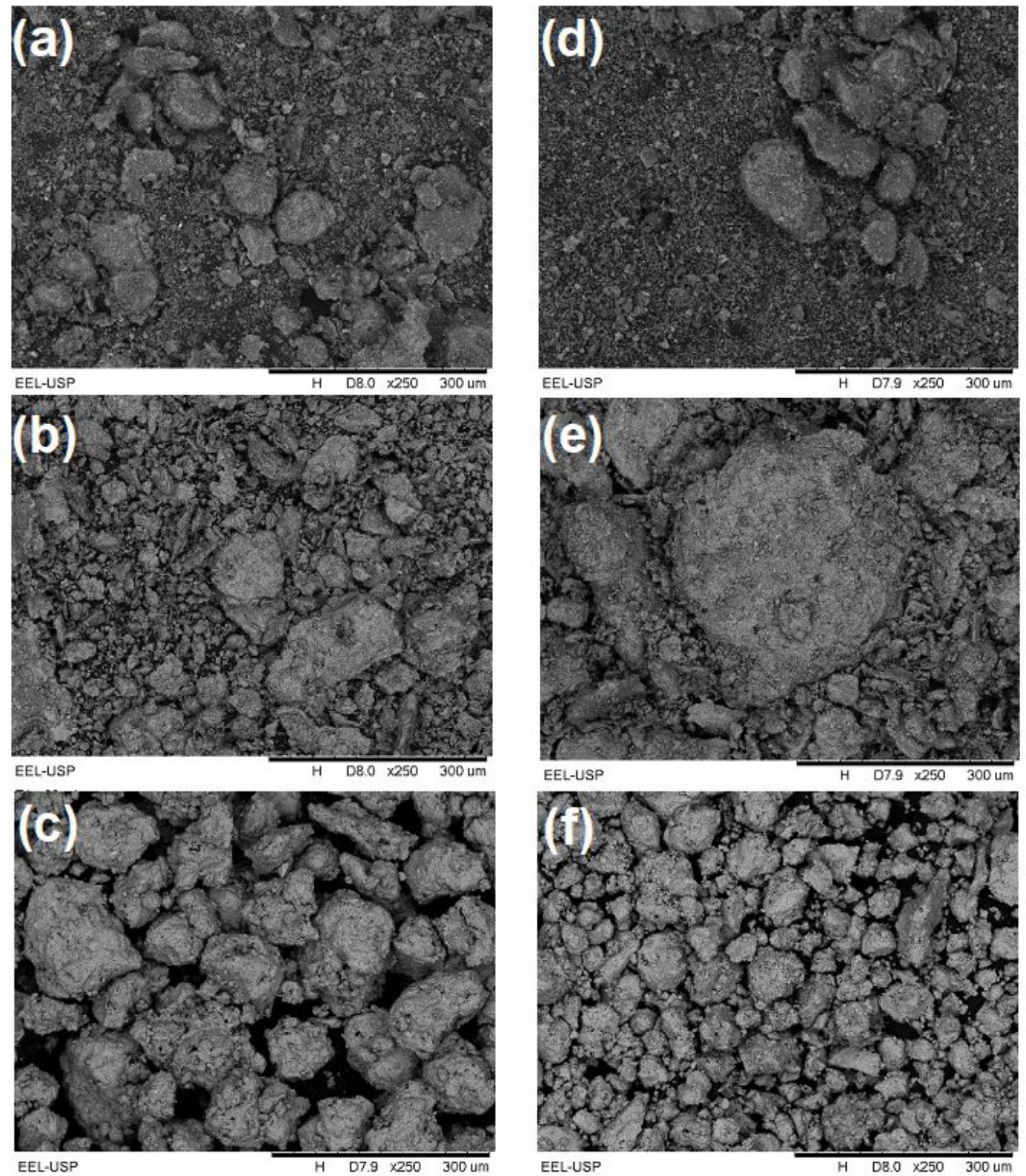

Figure 2. SEM micrographs of the (a-c) Ti-2Co-22Si-11B and (d-f) Ti-6Co-22Si-11B powder mixtures at different milling times: (a,d) $20 \mathrm{~min},(\mathrm{~b}, \mathrm{e}) 60 \mathrm{~min}$, and (c,f) $300 \mathrm{~min}$.

Table 4. Values of D10, D50 and D90 as well as the specific surface area measured by laser diffraction experiments in as-milled Ti-CoSi-B powders.

\begin{tabular}{cccccc}
\hline Composition Alloy (at.-\%) & Milling Time $(\mathbf{m i n})$ & $\mathbf{D 1 0}(\mu \mathrm{m})$ & $\mathbf{D 5 0}(\mu \mathrm{m})$ & $\mathbf{D 9 0}(\boldsymbol{\mu m})$ & \multicolumn{2}{c}{ Specific Surface Area $\left(\mathbf{m}^{2} / \mathbf{g}\right)$} \\
\hline \multirow{3}{*}{ 65Ti-2Co-22Si-11B } & 20 & 11.68 & 94.04 & 216.37 & 0.32 \\
\cline { 2 - 6 } & 60 & 25.05 & 119.50 & 391.07 & 0.17 \\
\cline { 2 - 6 } & 300 & 77.95 & 208.35 & 452.26 & 0.042 \\
\cline { 2 - 6 } 61Ti-6Co-22Si-11B & 20 & 11.36 & 101.59 & 227.17 & 0.34 \\
\cline { 2 - 6 } & 60 & 24.97 & 115.53 & 403.11 & 0.16 \\
\hline \multirow{2}{*}{} & 300 & 26.51 & 88.81 & 473.68 & 0.12 \\
\hline
\end{tabular}

65Ti-2Co-22Si-11B / 61 Ti-6Co-22Si-11B powder mixtures, as are illustrated in Figure 3.

XRD patterns of the SPSed 65Ti-2Co-22Si-11B and $61 \mathrm{Ti}-6 \mathrm{Co}-22 \mathrm{Si}-11 \mathrm{~B}$ alloys previously milled at different times are presented in Figure 4. Results have indicated the presence of intense $\mathrm{Ti}_{5} \mathrm{Si}_{3}, \mathrm{TiB}$ and $\mathrm{Ti}_{6} \mathrm{Si}_{2} \mathrm{~B}$ peaks. It was noted that the relative intensity of $\mathrm{Ti}_{6} \mathrm{Si}_{2} \mathrm{~B}$ was reduced whereas that to the $\mathrm{Ti}_{5} \mathrm{Si}_{3}$ phase increased with the cobalt amount 

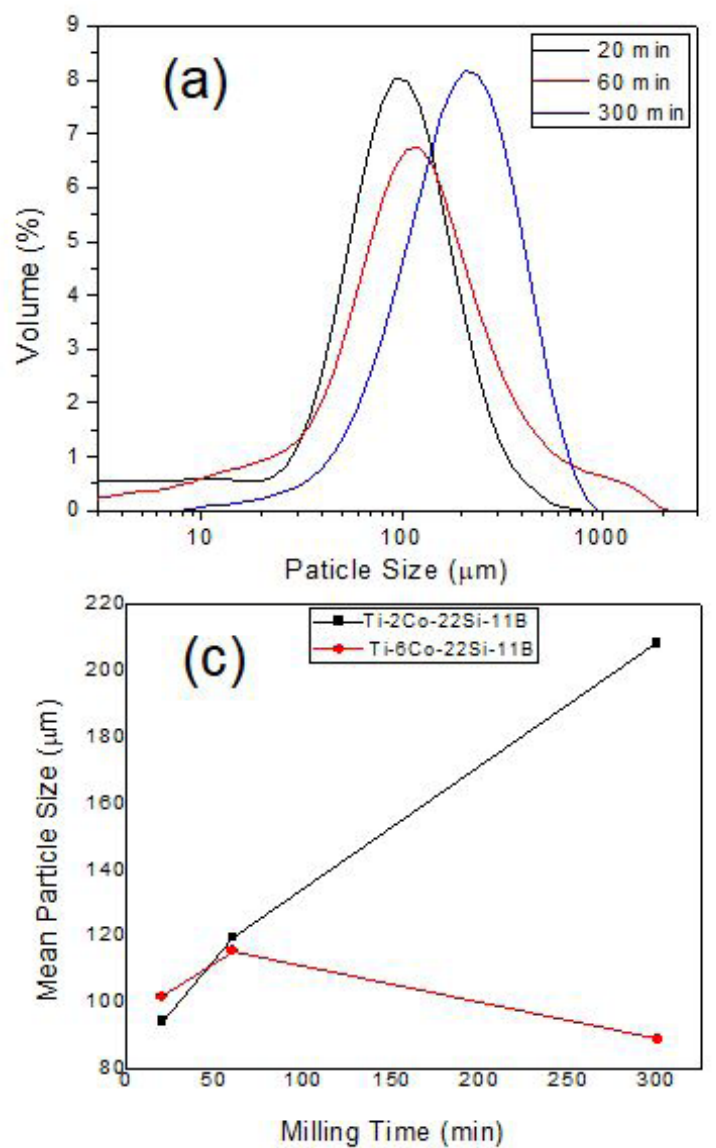
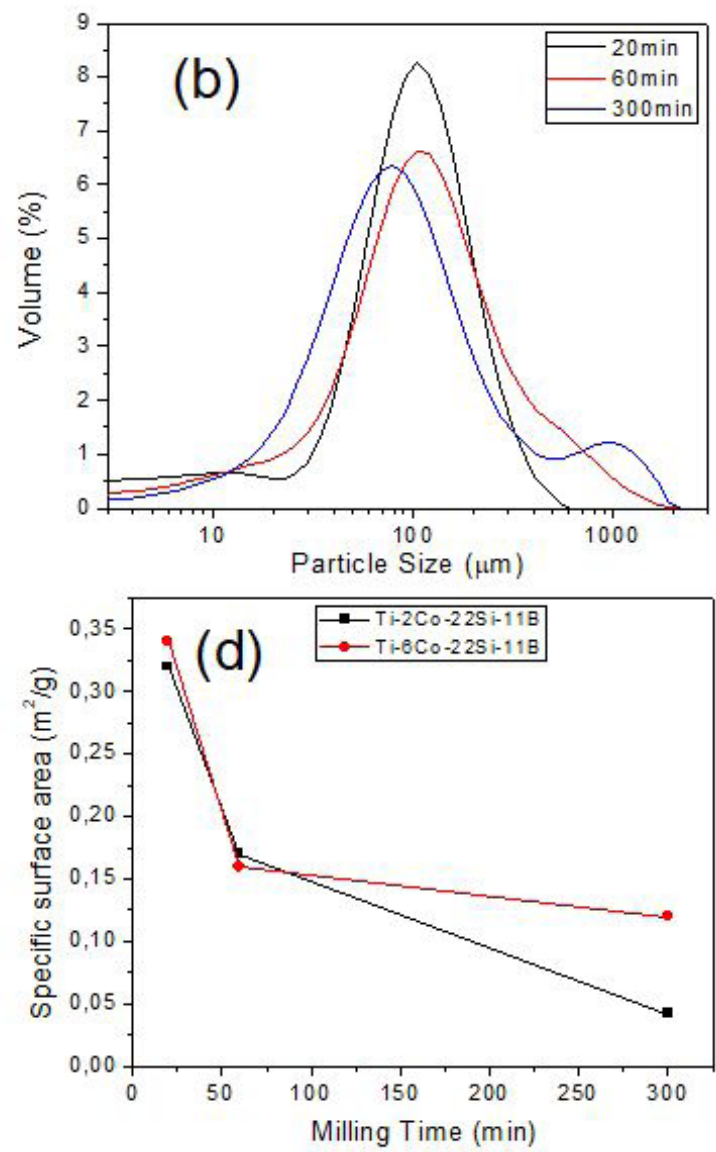

Figure 3. Particle size distribution curves of the (a) Ti-2Co-22Si-11B and (b) Ti-6Co-22Si-11B powder mixtures after different milling times. In (c) and (d), the effect of composition and milling time on the average particle sizes and specific surface areas of the Ti-Co-Si-B powders, respectively.

increased in the nominal alloy composition. Consequently, a larger amount of $\mathrm{TiB}$ is formed in microstructure of the SPSed 61Ti-6Co-22Si-11B alloy and its peaks more intense can be achieved. CoTi was also indexed in XRD patterns of the SPSed 61Ti-6Co-22Si-11B alloy produced with powders previously milled for 60 and $300 \mathrm{~min}$. Independent on adopted milling time, the minor TiC peaks were also identified in XRD patterns of these quaternary alloy, indicating that the carbon contamination was provided during spark plasma sintering.

Figure 5 shows the representative X-ray mapping of the $61 \mathrm{Ti}-6 \mathrm{Co}-22 \mathrm{Si}-11 \mathrm{~B}$ alloy which it was produced with powders milled for $300 \mathrm{~min}$. Results have revealed that the brighter regions in microstructure of this quaternary alloy are the richer Co sites, whereas its matrix contains the richer regions of $\mathrm{Si}$ and $\mathrm{B}$, i.e., probably the $\mathrm{Ti}_{6} \mathrm{Si}_{2} \mathrm{~B}$ and $\mathrm{Ti}_{5} \mathrm{Si}_{3}$ phases. In this way, titanium was uniformly distributed in both the matrix and others intermetallic precipitates. Boron was identified in dark regions with acicular morphology.

SEM micrographs of the (a-c) SPSed 65Ti-2Co-22Si$11 \mathrm{~B}$ and (d-f) $61 \mathrm{Ti}-6 \mathrm{Co}-22 \mathrm{Si}-11 \mathrm{~B}$ alloys produced with powders previously milled for, 20, 60 and $300 \mathrm{~min}$ are presented in Figure 6. The microstructures of these alloys presented very small amounts of pores, indicating that the parameters used in SPS process were effectives to obtain dense materials. In general, all the sintered samples showed high relative density, greater than $97 \pm 2 \%$, inferring that the SPS process has allowed the densification of the samples at $1100{ }^{\circ} \mathrm{C}-12 \mathrm{~min} / 20 \mathrm{MPa}$.

Despite the short milling (20 min) and sintering (12 min) times adopted for processing of these quaternary alloys, the atomic diffusion happened and the binary and ternary phases were formed in their microstructures. $\alpha-\mathrm{Ti}_{1} \mathrm{Ti}_{6} \mathrm{Si}_{2} \mathrm{~B}$ (matrix), $\mathrm{Ti}_{5} \mathrm{Si}_{3}$ and $\mathrm{TiB}$ were formed in microstructures of the SPSed 65Ti-2Co-22Si-11B alloy produced with powders milled for 20 and $60 \mathrm{~min}$. It was also noted the presence of Co-rich precipitates located in brighter regions of the SPSed 65Ti-2Co-22Si-11B alloy produced with powders milled for $300 \mathrm{~min}$. Independent on milling time, it was identified the existence of cracks in some regions of the SPSed 61Ti6Co-22Si-11B alloy, which are related to the $\mathrm{Ti}_{5} \mathrm{Si}_{3}$ phase with high crystallographic anisotropy in accordance with previous works ${ }^{6-9}$. The microstructure of the SPSed 61Ti$6 \mathrm{Co}-22 \mathrm{Si}-11 \mathrm{~B}$ alloy produced with powders milled for $20 \mathrm{~min}$ has indicated the major $\mathrm{Ti}_{5} \mathrm{Si}_{3}$ presence beside the $\alpha$-Ti, TiB and $\mathrm{Ti}_{6} \mathrm{Si}_{2} \mathrm{~B}$ precipitates. Nonetheless, the $\mathrm{Co}$-rich phases in brighter regions were also observed in microstructures of the $61 \mathrm{Ti}-6 \mathrm{Co}-22 \mathrm{Si}-11 \mathrm{~B}$ alloy produced with powders milled for 60 and 300 min only.

EDS results showing the typical $\mathrm{Ti}, \mathrm{Co}$ and $\mathrm{Si}$ contents of phases formed in microstructures of the SPSed 65Ti- 

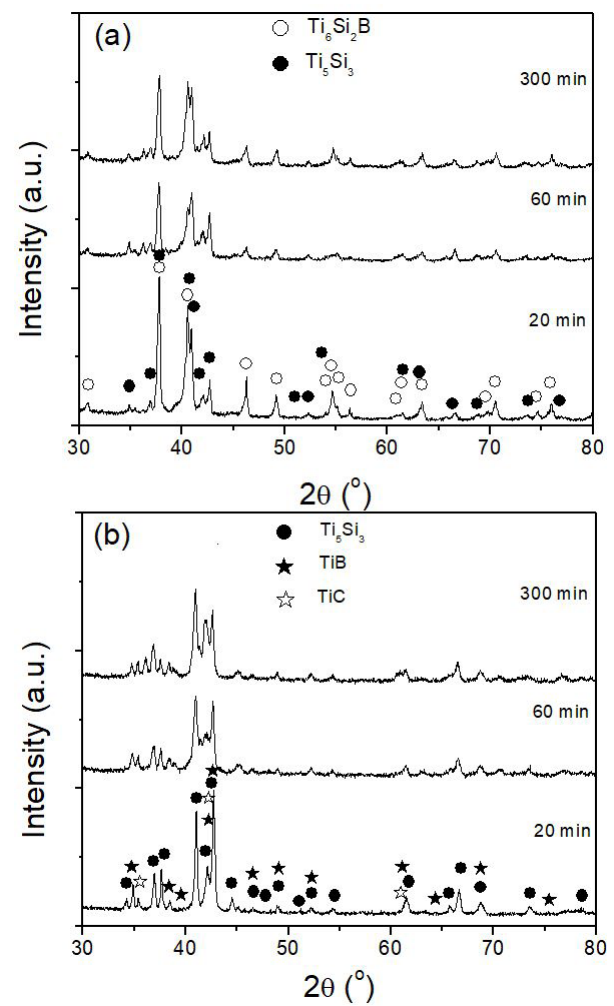

Figure 4. XRD patterns of the spark plasma sintered (a) Ti-2Co22Si-11B and (b) Ti-6Co-22Si-11B alloys produced with powders previously milled for $20 \mathrm{~min}, 60 \mathrm{~min}$ and $300 \mathrm{~min}$.
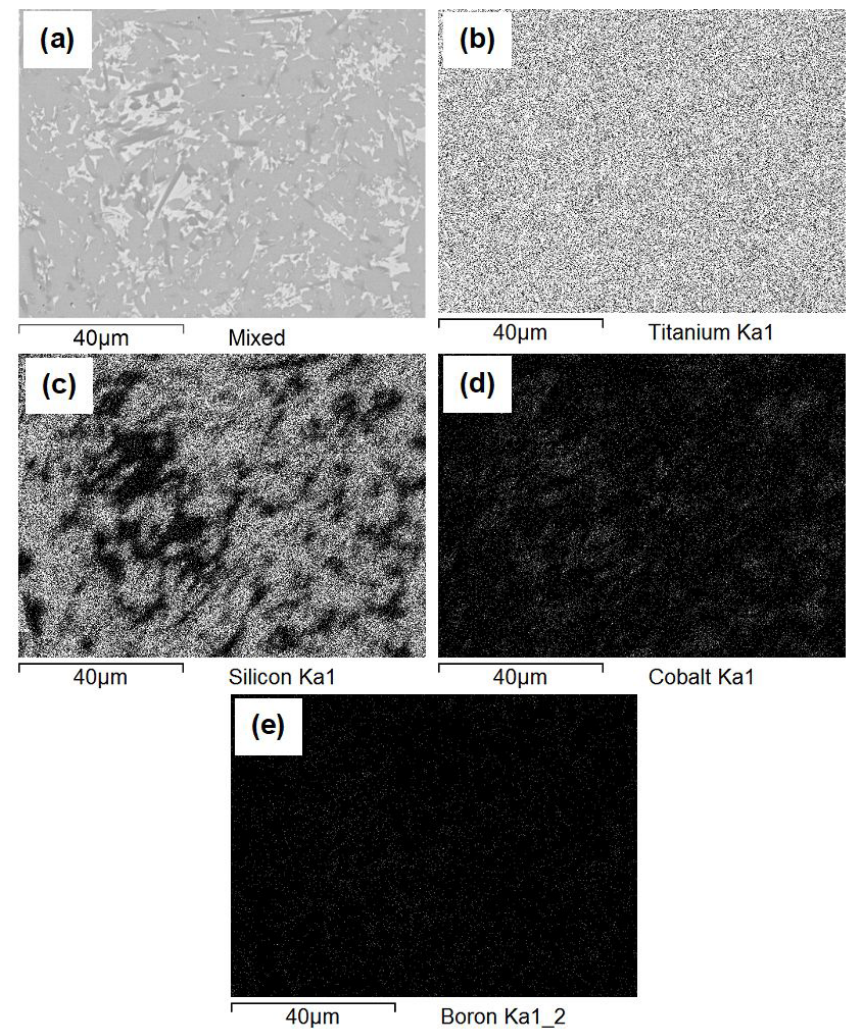

Figure 5. X-ray mapping of the SPSed Ti-6Co-22Si-11B alloy produced with powders milled for 300 min, showing the elemental distribution in its microstructure: (a) pattern, (b) titanium, (c) silicon, (d) cobalt, and (e) boron. with powders milled at different times are presented in Table 5. Values with asterisk were measured in alloys produced from the powders milled for $300 \mathrm{~min}$. In SPSed 65Ti-2Co-22Si-11B alloy, the $\alpha$-Ti regions have presented the $\mathrm{Si}$ and Co contents between 1.7-3.7 and 0.3-3.3 at-\%, respectively. $\mathrm{TiB}$ has dissolved $1.7-5.7$ at- $\% \mathrm{Si}$ and $0-0.2$ at- $\% \mathrm{Co}$, whereas the ternary $\mathrm{Ti}_{6} \mathrm{Si}_{2} \mathrm{~B}$ phase exhibited 20.1-27.5 at-\% Si and 0.1-2.7 at-\% Co. It is interesting to note that the $\mathrm{Ti}_{5} \mathrm{Si}_{3}$ has dissolved smaller amounts of Co $(<0.8$ at- $\%)$ than the $\mathrm{Ti}_{6} \mathrm{Si}_{2} \mathrm{~B}$ phase. Moreover, the highest $\mathrm{Co}$ amounts in $\mathrm{Ti}_{6} \mathrm{Si}_{2} \mathrm{~B}$ and $\mathrm{Ti}_{5} \mathrm{Si}_{3}$ were measured in SPSed 65Ti-2Co-22Si-11B alloy produced from the powders milled for $300 \mathrm{~min}$. As expected, the better chemical uniformity and smaller diffusion paths needed to atomic dissolution has happened in powder particles for longer milling times. Others brighter regions containing 4.6-8 and 16.7-20.6 at- $\%$ Co were also detected in microstructures of $65 \mathrm{Ti}-2 \mathrm{Co}-22 \mathrm{Si}-11 \mathrm{~B}$ alloys produced with powders milled for 20 (and 60) and $300 \mathrm{~min}$, respectively. Independent on the milling time, the nominal alloy composition of this quaternary SPSed alloy was confirmed by EDS results, which had the Si and Co contents close to 22.8-26.4 and 1.7-1.9 at-\%, respectively.

$\mathrm{Ti}_{6} \mathrm{Si}_{2} \mathrm{~B}$ presented 17.2 at- $\% \mathrm{Si}$ and 0.5 at- $\%$ Co in microstructure of the SPSed 61Ti-6Co-22Si-11B alloy produced with powders milled for $20 \mathrm{~min}$. $\mathrm{Ti}_{6} \mathrm{Si}_{2} \mathrm{~B}$ was not identified in microstructures of this quaternary alloy produced with powders milled for 60 and $300 \mathrm{~min}$. In microstructures of this alloy produced with powders milled
2Co-22Si-11B and 61Ti-6Co-22Si-11B alloys produced 
for 20 (and 60) and $300 \mathrm{~min}$, the $\mathrm{Ti}_{5} \mathrm{Si}_{3}$ phase presented the Si contents varying between $35.5-36.8$ and 30.6-35.7 at- $\%$, whereas the Co contents were in the range of 1.3-1.7 and $1.9-4.2$ at- $\%$, respectively. TiB dissolving up to 5.5 at- $\% \mathrm{Si}$ and 2.7 at- $\%$ Co were measured in microstructures of these quaternary alloy produced with powders milled for $300 \mathrm{~min}$. Our results have indicated that a more pronounced Co dissolution in $\mathrm{Ti}_{5} \mathrm{Si}_{3}$ and $\mathrm{TiB}$ was favored with increasing the Co amount in starting powders milled at longer times. Moreover, the CoTi phase was' identified in brighter regions of these quaternary alloy produced with powders milled for
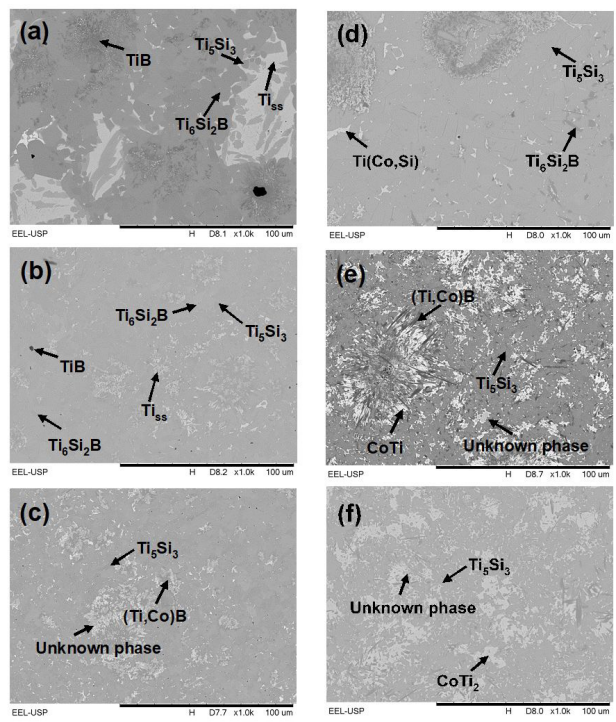

Figure 6. SEM micrographs of the SPSed (a-c) Ti-2Co-22Si-11B and (d-f) Ti-6Co-22Si-11B alloys produced with p'owders milled at different times: (a,d) $20 \mathrm{~min},(\mathrm{~b}, \mathrm{e}) 60 \mathrm{~min}$, and $(\mathrm{c}, \mathrm{f}) 300 \mathrm{~min}$.
20 and $60 \mathrm{~min}$, which presented the $\mathrm{Si}$ and Co contents in the range of 4.6-4.7 and 41.3-43.0 at-\%, respectively. Moreover, it was noted the presence of others bright regions containing 4.4-16.7 at- $\% \mathrm{Si}$ and $15.6-26.2$ at- $\%$ Co in this quaternary alloy produced with powders milled for $300 \mathrm{~min}$, which are related to the $\mathrm{CoTi}_{2}$ phase. However, an unknown phase containing close to 25 at- $\%$ Co (dissolving some Si amount) was found in microstructures of the SPSed 65Ti-2Co-22Si11B (300 $\mathrm{min})$ and 61 Ti-6Co-22Si-11B (60 and $300 \mathrm{~min}$ ) alloys, suggesting to be the $\mathrm{CoTi}_{3}$ phase. However, this binary phase is not reported in the phase diagram of the Co-Ti system ${ }^{13}$. Despite the presence of TiC peaks in XRD pattern of SPSed 61 Ti-6Co-22Si-11B alloy no evidence was found in EDS analysis by SEM.

The Vickers microhardness values of the SPSed 65Ti2Co-22Si-11B and 61Ti-6Co-22Si-11B alloys produced with powders milled at different times are presented in Figure 7. Independent on the milling time, it was also noted that the Co-richer alloy exhibited the highest Vickers microhardness values, which can be related to the Co-rich intermetallic phases. The 65Ti-2Co-22Si-11B and 61 Ti-6Co-22Si-11B alloys presented the values between 950-1050 HV and 1050$1150 \mathrm{HV}$, respectively. In contrary, the SPSed Ti-2Zn-22Si11B alloy presented average Vickers hardness values higher than $1050 \mathrm{HV}$ whereas the SPSed Ti-6Zn-22Si-11B alloy varied between 970 and $1036 \mathrm{HV}$, which were associated with the $\mathrm{Ti}_{6} \mathrm{Si}_{2} \mathrm{~B}$ formation ${ }^{4}$. Considering the SPSed Ti-Co22Si-11B and Ti-2Sn-22Si-11B alloys are based on $\mathrm{Ti}_{6} \mathrm{Si}_{2} \mathrm{~B}$ as matrix, and both the $\mathrm{Co}$ and Tin solubility limits in $\mathrm{Ti}_{6} \mathrm{Si}_{2} \mathrm{~B}$ are closed to 2 at- $\%$, their Vickers microhardness values of these quaternary alloys can be related with a more effective ( $\mathrm{Ti}, \mathrm{Sn})_{6} \mathrm{Si}_{2} \mathrm{~B}$ solution strengthening.

Nonetheless, the Ti-28Nb-7Ta-5Zr-10Hap alloy produced by mechanical alloying and spark plasma sintering has exhibited microhardness close to $537 \mathrm{HV}^{23}$. The Vickers

Table 5. Typical Ti, Si and Co (at.-\%) contents measured by EDS analysis in phases formed of the SPSed 65Ti-2Co-22Si-11B and 61Ti6Co-22Si-11B alloys produced with powders milled for 20 and $300 \mathrm{~min}$.

\begin{tabular}{|c|c|c|c|}
\hline \multicolumn{4}{|c|}{ 65Ti-2Co-22Si-11B } \\
\hline Phase & Ti (\%-at.) & Si (\%-at.) & Co (\%-at.) \\
\hline Ti & $98.0-93.0$ & $1.7-3.7$ & $0.3-3.3$ \\
\hline $\mathrm{Ti}_{6} \mathrm{Si}_{2} \mathrm{~B}$ & $77.1 *-72.2$ & $20.1^{*}-27.5$ & $0.1-1.7 / 2.7^{*}$ \\
\hline $\mathrm{Ti}_{5} \mathrm{Si}_{3}$ & $63.0 *-68.0$ & $31.4-36.2 *$ & $0.6-0.8^{*}$ \\
\hline TiB & $98.2-94.3$ & $1.7-5.7$ & $0.2-0$ \\
\hline ND & $89.2-89.8$ & $2.8-5.5$ & $8.0-4.6$ \\
\hline ND & $81.7^{*}-77.4^{*}$ & $1.6^{*}-2.0^{*}$ & $16.7^{*}-20.6^{*}$ \\
\hline Global & $71.7 *-75.5$ & $22.8-26.4^{*}$ & $1.7-1.9^{*}$ \\
\hline \multicolumn{4}{|c|}{ 61Ti-6Co-22Si-11B } \\
\hline Phase & Ti (at.-\%) & Si (at.-\%) & Co (at.-\%) \\
\hline $\mathrm{Ti}_{6} \mathrm{Si}_{2} \mathrm{~B}$ & $82.3-77.8$ & $17.2-23.2$ & $0-0.5$ \\
\hline $\mathrm{Ti}_{5} \mathrm{Si}_{3}$ & $61.4-63.2$ & $36.8-35.5$ & $1.7-1.3$ \\
\hline CoTi & $52.3-54.1$ & $4.7-4.6$ & $43.0-41.3$ \\
\hline Global & $65.6-65.7$ & $29.3-29.2$ & $5.1-5.0$ \\
\hline$* \mathrm{TiB}$ & $97.8-91.8$ & $1.1-5.5$ & $1.2-2.7$ \\
\hline$* \mathrm{Ti}_{5} \mathrm{Si}_{3}$ & $62.9-65.2$ & $35.7-30.6$ & $1.9-4.2$ \\
\hline *ND & $74.9-78.5$ & $2.1-2.1$ & $23.1-19.4$ \\
\hline$* \mathrm{CoTi}_{2}$ & $69.5-67.7$ & $4.4-16.7$ & $26.2-15.6$ \\
\hline
\end{tabular}

\footnotetext{
ND - Not Determined; * measured in alloy produced with powders milled for $300 \mathrm{~min}$.
} 


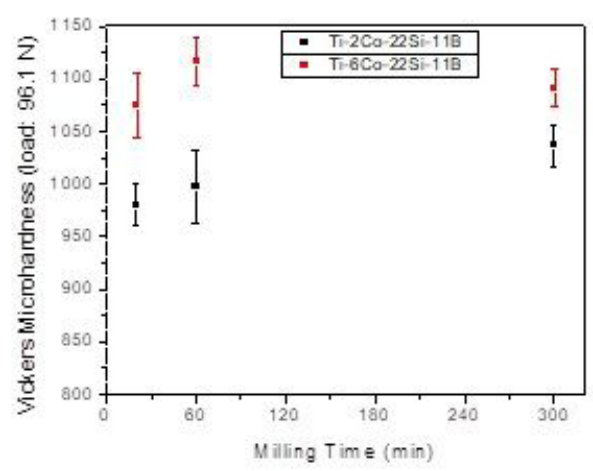

Figure 7. Vickers Hardness values of the SPSed (a-c) Ti-2Co-22Si$11 \mathrm{~B}$ and (d-f) Ti-6Co-22Si-11B alloys produced with powders milled at different times: (a,d) $20 \mathrm{~min},(\mathrm{~b}, \mathrm{e}) 60 \mathrm{~min}$, and (c,f) $300 \mathrm{~min}$.

hardness values of homogenized Ti-48Al-2Cr and Ti-48Al$2 \mathrm{Cr}-2 \mathrm{Nb}$ alloys varied from 274 and 542 to 303 and 610 $\mathrm{HV}$, respectively ${ }^{24}$. In these alloys, the higher hardness in the quaternary alloy is due to the presence of larger amounts of lamellar phase as compared to ternary alloy where the amount of $\gamma$ phase rich regions is found to be greater. However, the mechanically alloyed and spark plasma sintered Ti-Co-Si-B alloys evaluated in this work have presented higher Vickers hardness than others alloys used to biomedical, automotive and aerospace applications.

\section{Conclusions}

Longer milling times (300 $\mathrm{min}$ ) contributed to reach the chemical and microstructural homogeneities in the 65Ti2Co-22Si-11B and 61Ti-6Co-22Si-11B powder mixtures, and supersaturated $\alpha$-Ti solid solutions were achieved.

Spark plasma sintering produced dense $65 \mathrm{Ti}-2 \mathrm{Co}-22 \mathrm{Si}-11 \mathrm{~B}$ and 61Ti-6Co-22Si-11B alloys. Despite the short sintering time (12 $\mathrm{min}$ ), the equilibrium microstructures were reached using powders milled for longer times.

The increase of Co in the nominal alloy composition has reduced the $\mathrm{Ti}_{6} \mathrm{Si}_{2} \mathrm{~B}$ amount in microstructures of the SPSed Ti-Co-Si-B alloys, and others Co-rich phases were preferentially formed.

Vickers hardness values of the SPSed 65Ti-2Co-22Si-11B and 61 Ti-6Co-22Si-11B alloys were close to 950-1050 HV and 1050-1150 HV, respectively.

\section{Acknowledgments}

Authors thank to FAPESP (grants \#2001/03961-4 and \#2007/50018-2)-, CAPES-, FAPEMIG-, CNPq (grant \#313052/2019-7)- and FINEP-Brazil for the financial supports needed in development of this work.

\section{References}

1. Kato MKN, Onari E, Arisawa EAL, Silva NS, Ramos AS. Osseointegration features of orthopedic Ti-10Si-5B implants. Mater Sci Eng C. 2009;29(3):980-6. http://dx.doi.org/10.1016/j. msec.2008.08.022.

2. Fernandes BB, Ueda M, Savonov GS, Moura C No, Ramos AS. Surface corrosion of Ti-16Si-4B powder alloy implanted with nitrogen by plasma-based technique. IEEE Transactions on Plasma Science. 2011;39(11):3061-66. https://doi.org/10.1109/ TPS.2011.2159031.

3. Samarov V, Seliverstov D, Froes FH (Sam). 18 - Fabrication of near-net-shape cost-effective titanium components by use of prealloyed powders and hot isostatic pressing. Qian M Froes FH (Sam), editors. Titanium powder metallurgy: science, technology and applications. Oxônia: Butterworth-Heinemann; 2015. p. 313-6. https://doi.org/10.1016/B978-0-12-800054-0.00018-6.

4. Ferreira ND, Leal RM No, Filgueira M, Ferreira LM, Alves MFRP, Ramos ECT, et al. Microstructure and Vickers hardness of mechanically alloyed and spark plasma sintered Ti-2Zn-22Si-11B and Ti-6Zn-22Si-11B alloys. J Alloys Compd. 2019;794:61524. http://dx.doi.org/10.1016/j.jallcom.2019.04.172.

5. Rossi LB, Ferreira LM, Freitas BX, Nunes CA, Ramos AS, Filgueira $\mathrm{M}$, et al. Mechanical alloying and hot pressing of Ti-Zr-Si-B powder mixtures. Metals (Basel). 2018;8:82-94. http://dx.doi.org/10.3390/met8020082.

6. Matković T, Slokar L, Matković P. Structure and properties of biomedical Co-Cr-Ti alloys. J Alloys Compd. 2006;407(12):294-8. http://dx.doi.org/10.1016/j.jallcom.2005.06.025.

7. Weng W, Biesiekierski A, Li Y, Wen C. Effects of selected metallic and interstitial elements on the microstructure and mechanical properties of beta titanium alloys for orthopedic applications. Materialia. 2019;6:100323. http://dx.doi. org/10.1016/j.mtla.2019.100323.

8. Niinomi M. 4.1 - Titanium spinal-fixation implants. In Froes FH, Qian M, editors. Titanium in medical and dental applications. Cambridge: Woodhead Publishing; 2018. p. 347-69 (Woodhead Publishing Series in Biomaterials). http://dx.doi.org/10.1016/ B978-0-12-812456-7.00016-0.

9. Mutlu I. Synthesis and characterization of Ti-Co alloy foam for biomedical applications. Trans Nonferrous Met Soc China. 2016;26(1):126-37. http://dx.doi.org/10.1016/S10036326(15)64028-6.

10. Xue Y, Wang HM. Microstructure and dry sliding wear resistance of CoTi intermetallic alloy. Intermetallics. 2009;17(3):89-97. http://dx.doi.org/10.1016/j.intermet.2008.06.010.

11. Straumal BB, Kilmametov AR, Ivanisenko Y, Mazilkin AA, Hahn H. Diffusive and displacive phase transitions in $\mathrm{Ti}-\mathrm{Fe}$ and Ti-Co alloys under high-pressure torsion. J Alloys Compd. 2018;735:2281-6. http://dx.doi.org/10.1016/j.jallcom.2017.11.317.

12. Borrell A, Salvador MD, Rocha VG, Fernández A, Gotor FJ. Bulk TiCxN1-x-15\%Co cermets obtained by direct spark plasma sintering of mechanochemical synthesized powders. Mater Res Bull. 2012;47(12):4487-90. http://dx.doi.org/10.1016/j. materresbull.2012.09.066.

13. Murray JL. The Co-Ti (Cobalt-Titanium) system. In: Okamoto H., Schlesinger ME, Mueller E.M., editors. Binary alloy phase diagrams. Vol. 3. New York: ASM International; 2016. p. 674-5. https://doi.org/10.31399/asm.hb.v03.9781627081634.

14. Villars P, Cenzual K. Pearson's crystal data: crystal structure database for inorganic compounds (on DVD), release 2018/19. Materials Park: ASM International.

15. Kraus W, Nolze G. Powdercell: a program for the representation and manipulation of crystal structures and calculation of the resulting X-ray powder patterns. J Appl Cryst. 1996;29:301-3. http://dx.doi.org/10.1107/S0021889895014920.

16. Rietveld HM. A profile refinement method for nuclear and magnetic structures. J Appl Cryst. 1969;2:65-71. http://dx.doi. org/10.1107/S0021889869006558.

17. Scherrer P. Bestimmung der Größe und der inneren Struktur von Kolloidteilchen mittels Röntgenstrahlen. Nachrichten von der Gesellschaft der Wissenschaften zu Göttingen, Abh. Math.-Phys. K1. [serial on the Internet]. 1918 [cited 2020 Jul 22];2:98-100. Available from: http://www.digizeitschriften.de/ $\mathrm{dms} /$ resolveppn/?PID=GDZPPN002505045 
18. Patterson AL. The scherrer formula for X-ray particle size determination. Phys Rev. 1939;56(10):978-82. http://dx.doi. org/10.1103/PhysRev.56.978.

19. ASTM International. ASTM E384-17: Standard Test Method for Microindentation Hardness of Materials. West Conshohocken: ASTM; 2017.

20. Predel B. B - Ti (Boron - Titanium). In: Landolt-Börnstein - Group IV Physical Chemistry, B-Ba - Cu-Zr. USA: Springer-Verlag Berlin Heidelberg; 2012. https:// dx.doi.org/10.1007/978-3540-44756-6 41.

21. Fiore M, Beneduce F No, Azevedo CRF. Assessment of the Ti-Rich corner of the Ti-Si phase diagram: the recent dispute about the eutectoid reaction. Mater Res. 2016;19(4):942-53. http://dx.doi.org/10.1590/1980-5373-MR-2016-0157.
22. Suryanarayana C. Mechanical alloying and milling. Prog Mater Sci. 2001;46(1-2):1-184. http://dx.doi.org/10.1016/S00796425(99)00010-9.

23. Bhushan B, Singh A, Singh R, Mehta JS, Prakash C. Fabrication and characterization of a new range of $\beta$-type Ti-Nb-Ta-Zr-xHaP $(\mathrm{x}=0,10)$ alloy by mechanical alloying and spark plasma sintering for biomedical applications. Mater Today. 2018;5(14):27749-56. http://dx.doi.org/10.1016/j.matpr.2018.10.010.

24. Gupta RK, Pant B, Agarwala V, Agarwala RC, Sinha PP. Evaluation of $\mathrm{Ti}$ aluminide intermetallics processed through reaction synthesis. High-Temp Mater Process. 2009;28(3):12132. http://dx.doi.org/10.1515/HTMP.2009.28.3.121. 